\title{
Metal ion-binding properties of L-glutamic acid and L-aspartic acid, a comparative investigation
}

\author{
S. A. A. Sajadi
}

Sharif University of Technology, Institute of Water \& Energy, Tehran, Iran; sajadi@sharif.ac.ir

Received 14 November 2009; revised 9 December 2009; accepted 30 December 2009.

\begin{abstract}
A comparative research has been developed for acidity and stability constants of $M(\mathrm{Glu})^{1}$, $M(A s p)^{2}$ and $M(T t r)^{3}$ complexes, which have been determined by potentiometric $\mathrm{pH}$ titration. Depending on metal ion-binding properties, vital differences in building complex were observed. The present study indicates that in $M(T t r)$ complexes, metal ions are arranged to the carboxyl groups, but in $M(\mathrm{Glu})$ and $M(A s p)$, some metal ions are able to build chelate over amine groups. The results mentioned-above demonstrate that for some $M(G / u)$ and $M(A s p)$ complexes, the stability constants are also largely determined by the affinity of metal ions for amine group. This leads to a kind of selectivity of metal ions, and transfers them through building complexes accompanied with glutamate and aspartate. For heavy metal ions, this building complex helps the absorption and filtration of the blood plasma, and consequently, the excursion of heavy metal ions takes place. This is an important method in micro-dialysis. In this study the different aspects of stabilization of metal ion complexes regarding to Irving-Williams sequence have been investigated.
\end{abstract}

Keywords: Glutamic Acid; Aspartic Acid; Tartaric Acid; Divalent Metal lons; Potentiometric Titration; Acidity and Stability Constants.

\section{INTRODUCTION}

It is known that metal ions are important for numerous biochemical reactions. For example, enzymes work only in the presence of such metal ions. The metal ion complexes of many amino acids have been investigated [1-6]. Functionalized membranes represent a field with multiple applications. Examination of specific metal-macromolecule interactions on these surfaces indicates an ex-

${ }^{1}$ L-Glutamic acid; ${ }^{2}$ L-Aspartic acid; ${ }^{3}$ L-Tartaric acid cellent method for characterization of these materials. Ion exchange, chelation, and electrostatic interactions form the basis of metal sorption. The behavior of various materials functionalized with polypeptides and other molecules is a topic of interest because of its applications in affinity separations, biosensors, and other applications including site-specific interactions [7]. An example of the latter involves the removal of heavy metals from aqueous solutions [8-11]. These sorbents are made of a variety of materials containing different functional groups. The advantage of affinity separations is that they may be tailored for the desired selectivity and capacity. The functionalization of materials is of vital importance for the production of new materials with specific properties. The characterization of these new materials is also critical. Previous investigations showed that for the "harder" ligands, the ionic term dominates and their binding energies are affected by changes in covalency over the series. It is the competition between these behaviors that produces the Irving-Williams series in stability constants [12]. L-glutamate and L-aspartate are key molecules in cellular metabolism (Figure 1). In humans, dietary proteins are broken down by digestion into amino acids, which serve as metabolic fuel for other functional roles in the body. Based on above-mentioned, the essential role of Glu is interesting to study the interaction between other metal ions with Glu and related compounds.

\section{EXPERIMENTAL}

\subsection{Materials}

The L-glutamic acid and L-aspartic acid (extra pure) was purchased from Merck, Darmstadt, Germany. The nitrate salt of $\mathrm{Na}^{+}, \mathrm{Ca}^{2+}, \mathrm{Mg}^{2+}, \mathrm{Mn}^{2+}, \mathrm{Co}^{2+}, \mathrm{Cu}^{2+}$, and $\mathrm{Zn}^{2+}$ (all pro analysis) were from Merck. All the starting materials were of reagent grade and used without further purification. Potassium hydrogen phthalate and standard solutions of sodium hydroxide (titrasol), nitric acid, EDTA and of the buffer solutions of $\mathrm{pH} 4.0,7.0$ and 9.0 were all from Merck. All solutions were prepared with deionized water. Water was purified by Milil-Q water purification system, de-ionized and distillated. 


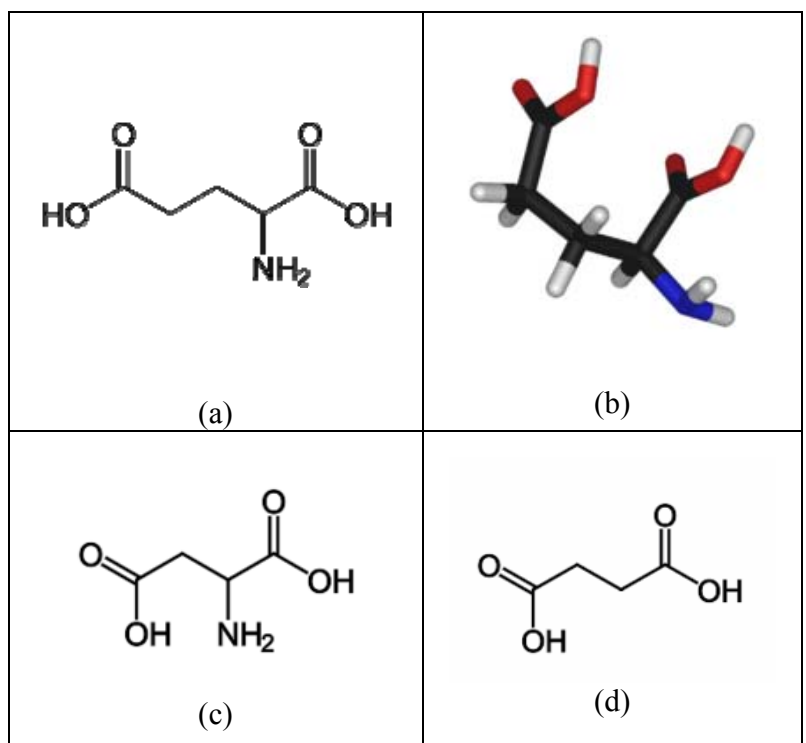

Figure 1. Chemical structures of (a, b) L-glutamic acid; (c) L-aspartic acid and; (d) tartaric acid.

\subsection{Ph Titrations}

\section{Reagents}

Carbonate-free sodium hydroxide $0.03 \mathrm{M}$ was prepared and standardized against sodium hydrogen phthalate and a standard solution of nitric acid $0.5 \mathrm{mM}$. M(II) nitrate solution $(0.03 \mathrm{M})$ was prepared by dissolving the above substance in water and was standardized with standard solution of EDTA 0.1 M (triplex).

\subsection{Apparatus}

All pH titrations were performed using a Metrohm 794 basic automatic titrator (Titrino), coupled with a thermostating bath Hero at $25^{\circ} \mathrm{C}\left( \pm 0.1^{\circ} \mathrm{C}\right)$ and a Metrohm combined glass electrode $(\mathrm{Ag} / \mathrm{AgCl})$. The $\mathrm{pH}$ meter was calibrated with Merck standard buffer solutions (4.0, 7.0 and 9.0).

\subsection{Procedure}

For the determination of acid dissociation constants of the ligand $\mathrm{L}$, an aqueous solution $(0.03 \mathrm{mM})$ of the protonated ligand was titrated with $0.03 \mathrm{M} \mathrm{NaOH}$ at $25^{\circ} \mathrm{C}$ under nitrogen atmosphere and ionic strength of $0.1 \mathrm{M}$, NaNO3. For the determination of binary (a ligand and $\mathrm{Cu} 2+)$ system, the ratios used were $1: 1, \mathrm{Cu}(\mathrm{II})$ : Ligand and $1: 1, \mathrm{Cu}(\mathrm{II}): \mathrm{L}, 0.3 \mathrm{mM}$. This solution was titrated with $0.03 \mathrm{M} \mathrm{NaOH}$ under the same conditions mentioned above. Each titration was repeated seven times in order to check the reproducibility of the data.

\subsection{Calculation}

The acid dissociation constants, $K_{H_{2}(L)}^{H}$ and $K_{H(L)}^{H}$ for
H2(L) were calculated by an algebraic method. The equilibria involved in the formation of 1:1 complex of $\mathrm{L}$ and a divalent metal ion may be expressed as Eqs.(710).

\section{RESULTS AND DISCUSSION}

The potentiometric $\mathrm{pH}$-titrations $\left(25^{\circ} \mathrm{C}, 0.1 \mathrm{M}, \mathrm{NaNO} 3\right)$ were carried out to obtain the acidity and stability constants which are summarized in Tables $\mathbf{1}$ and $\mathbf{2}$.

Acidity constants

L-glutamate $-\mathrm{O} 2 \mathrm{CCH} 2 \mathrm{CH} 2 \mathrm{CH}(\mathrm{NH} 2) \mathrm{CO} 2-$ and Laspartate ions (L2-), $-\mathrm{O} 2 \mathrm{CCH} 2 \mathrm{CH}(\mathrm{NH} 2) \mathrm{CO} 2-$, are two-basic species, and thus they can accept two protons, given $\mathrm{H} 2(\mathrm{~L})$, for which the following de-protonation equilibriums are hold:

$$
\begin{aligned}
& \mathrm{H}_{2}(\mathrm{~L}) \rightleftharpoons \mathrm{H}^{+}+\mathrm{H}(\mathrm{L})^{-} \\
& K_{H_{2}(L)}^{H}=\left[\mathrm{H}(\mathrm{L})^{-}\right]\left[\mathrm{H}^{+}\right] /\left[\mathrm{H}_{2}(\mathrm{~L})\right] \\
& \mathrm{H}(\mathrm{L})^{-} \rightleftharpoons \mathrm{H}^{+}+\mathrm{L}^{2-} \\
& K_{H(L)}^{H}=\left[\mathrm{L}^{2-}\right]\left[\mathrm{H}^{+}\right] /\left[\mathrm{H}(\mathrm{L})^{-}\right]
\end{aligned}
$$

The two proton in $\mathrm{H}_{2}(\mathrm{~L})$ are certainly bound at the terminal acetate and amino groups, i.e., it is released from $\mathrm{HO}_{2} \mathrm{CCH}_{2} \mathrm{CH}_{2} \mathrm{CH}\left(\mathrm{NH}_{3}{ }^{+}\right) \mathrm{CO}_{2}^{-} \mathrm{H}_{2} \mathrm{Glu}$ according to Equilibriums (1) and (2). It is known as zwitter-ion, and is also closed to the de-protonation of acetate groups which occurs at the terminal acetate groups of tartaric acid $[6,13] . \mathrm{L}^{2-}$ can release one more proton from the terminal acetate group. Hence, here due addition to Equilibrium (3) should be considered, which takes place above a $\mathrm{pH} \approx 2$ (see Figure 2).

$$
\begin{aligned}
\mathrm{H}_{3}(\mathrm{~L})^{+} & \rightleftharpoons \mathrm{H}^{+}+\mathrm{H}_{2}(\mathrm{~L}) \\
K_{H_{3}(L)}^{H} & =\left[\mathrm{H}_{2}(\mathrm{~L})\right]\left[\mathrm{H}^{+}\right] /\left[\mathrm{H}_{3}(\mathrm{~L})^{+}\right]
\end{aligned}
$$

Here, the aforementioned reaction is not considered further.

\subsection{Stability of Binary and Ternary Complexes}

If we abbreviate for simplicity associating with $\mathrm{Ca}^{2+}$, $\mathrm{Mg}^{2+}, \mathrm{Mn}^{2+}, \mathrm{Co}^{2+}, \mathrm{Cu}^{2+}$, and $\mathrm{Zn}^{2+}$ with $\mathrm{M}^{2+}$, then one may write the following two Equilibriums (4) and (5):

$$
\begin{aligned}
& \mathrm{M}^{2+}+\mathrm{H}(\mathrm{L})^{-} \rightleftharpoons \mathrm{M}(\mathrm{H} ; \mathrm{L})^{+} \\
& K_{M(H ; L)}^{M}=\left[\mathrm{M}(\mathrm{H} ; \mathrm{L})^{+}\right] /\left[\mathrm{M}^{2+}\right]\left[\mathrm{H}(\mathrm{L})^{-}\right] \\
& \mathrm{M}^{2+}+(\mathrm{L})^{2-} \rightleftharpoons \mathrm{M}(\mathrm{L}) \\
& K_{M(L)}^{M}=[\mathrm{M}(\mathrm{L})] /\left[\mathrm{M}^{2+}\right]\left[\mathrm{L}^{2-}\right]
\end{aligned}
$$

\subsection{Potentiometric Analyses}

These results are summarized in Tables $\mathbf{1}$ and $\mathbf{2}$. The data 


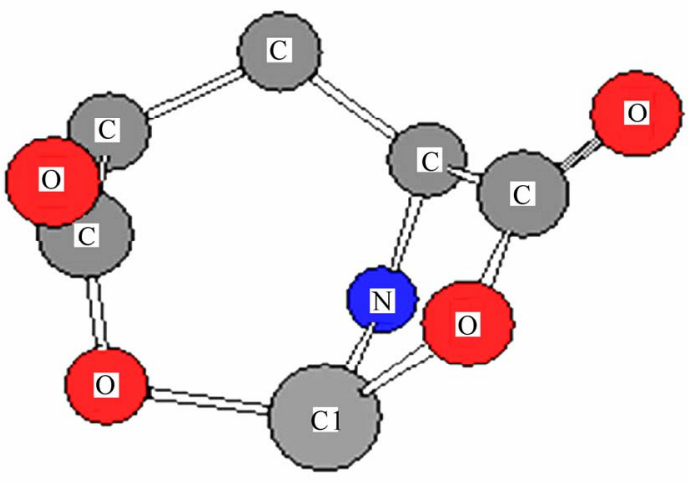

(a) $\mathrm{Cu}-\mathrm{Glu}$

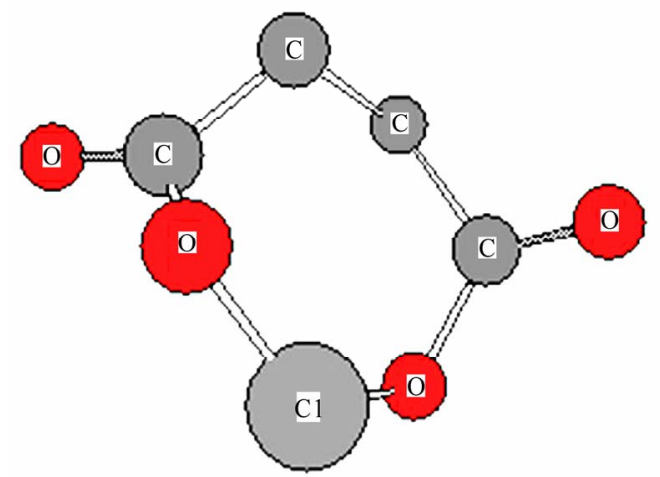

(b) $\mathrm{Cu}-\mathrm{Ttr}$

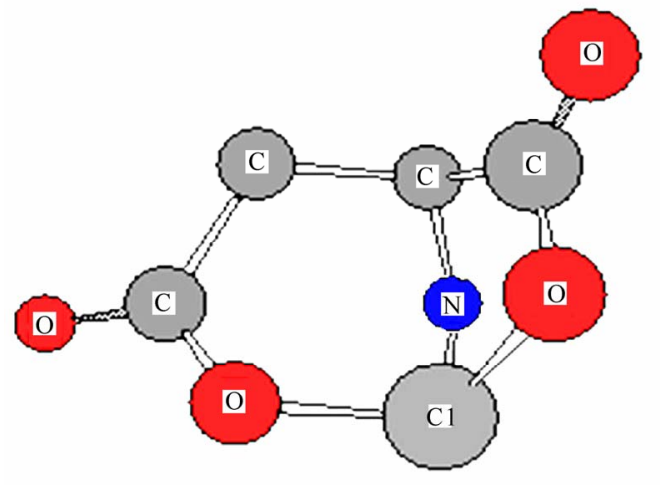

(c) $\mathrm{Cu}-\mathrm{Asp}$

Figure 2. Schematic structures of the species with interactions according to Equilibrium (5) for a) $\mathrm{Cu}(\mathrm{Glu})$, b) $\mathrm{Cu}(\mathrm{Asp})$ and c) $\mathrm{Cu}(\mathrm{Ttr})$. The structure in the right part of the figure was drawn with the programCS Chem 3D, version 3.5, from Cambridge Software Corporation.

Table 1. Negative logarithm of the acidiity constants of $\mathrm{H}_{3}(\mathrm{Asp})^{+}, \mathrm{H}_{2}(\mathrm{Ttr})^{+}$, and $\mathrm{H}_{3}(\mathrm{Glu})^{+}$at $25^{\circ} \mathrm{C}, 0.1 \mathrm{M}, \mathrm{NaNO}_{3}{ }^{*}$, Equilibriums (1), (2) \& (3).

\begin{tabular}{ccccc}
\hline & Asp & Ttr & Glu & Site \\
\hline \multirow{3}{*}{$\mathrm{pK}_{\mathrm{a}}$} & $1.99^{* *}$ & $3.09 \pm 0.07$ & $2.05 \pm 0.13$ & $-\mathrm{CO}_{2} \mathrm{H}$ \\
& $3.72 \pm 0.03$ & $4.19 \pm 0.05$ & $4.37 \pm 0.03$ & $-\mathrm{CO}_{2} \mathrm{H}$ \\
& $9.90 \pm 0.03$ & - & $9.98 \pm 0.02$ & $-\mathrm{NH}_{3}$ \\
\hline
\end{tabular}

*The given errors are three times the standard error of the mean value or the sum of the propabable systematic errors. ${ }^{* *}[6]$
Table 2. Comparison of the stability constants of binary complexes of Asp, Ttr and Glu with $\mathrm{M}^{2+}$ at $25^{\circ} \mathrm{C}, I=0.1 \mathrm{M}$, $\mathrm{NaNO}_{3}{ }^{*}$.

\begin{tabular}{ccccc}
\hline No. & Species & $\log K_{M(\text { Asp })}^{M}$ & $\log K_{M(\text { Trr })}^{M}$ & $\log K_{M(\text { Glu })}^{M}$ \\
\hline 1 & $\mathrm{Mg}^{2+}$ & $2.50 \pm 0.06$ & $1.90 \pm 0.05$ & $1.82 \pm 0.06$ \\
2 & $\mathrm{Ca}^{2+}$ & $1.26 \pm 0.06$ & $1.80 \pm 0.05^{1}$ & $1.41 \pm 0.02$ \\
3 & $\mathrm{Mn}^{2+}$ & $3.91 \pm 0.03$ & $4.08 \pm 0.08$ & $3.19 \pm 0.08$ \\
4 & $\mathrm{Co}^{2+}$ & $6.69 \pm 0.06$ & $3.27 \pm 0.08$ & $4.15 \pm 0.09$ \\
5 & $\mathrm{Cu}^{2+}$ & $8.78 \pm 0.02$ & $3.65 \pm 0.07$ & $7.70 \pm 0.09$ \\
6 & $\mathrm{Zn}^{2+}$ & $5.35 \pm 0.06$ & $2.69 \pm 0.07$ & $5.84 \pm 0.03$ \\
\hline
\end{tabular}

*The given errors are three times the standard error of the meanvalue or the sum of the propabable systematic errors. ${ }^{1}[6,14]$

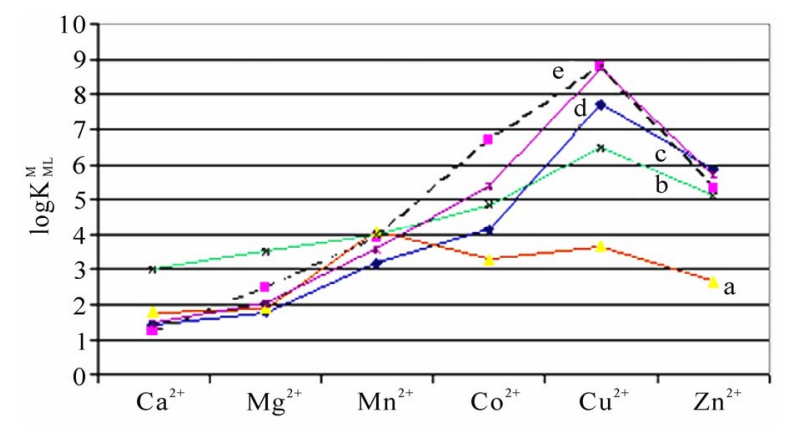

Figure 3. Irving-Willams sequence-type plot for the 1:1 complexes of $\mathrm{Ca}^{2+}, \mathrm{Mg}^{2+}, \mathrm{Mn}^{2+}, \mathrm{Co}^{2+}, \mathrm{Cu}^{2+}$, and $\mathrm{Zn}^{2+}$ formed with. a) Tartarate $\left.\left(\mathrm{Ttr}^{2-}\right) ; \mathrm{b}\right)$ oxalate $\left(\mathrm{Ox}^{2-}\right)$; c) glutamate $\left(\mathrm{Glu}^{2-}\right)$; $)$ glycine $\left(\mathrm{Gly}^{-}\right)$; e) aspartate $\left(\mathrm{Asp}^{2-}\right)$; The data are taken from Table 2 and [15], they represent also the stability constants of $\mathrm{M}^{2+}$ complexes of $\mathrm{L}\left(25^{\circ} \mathrm{C}, 0.1 \mathrm{M}, \mathrm{NaNO}_{3}\right)$.

in Table 1 present the acidity constants $\mathrm{pK}_{\mathrm{a}}\left(K_{H(L)}^{H}\right.$, $K_{H_{2}(L)}^{H}$, and $\left.K_{H_{3}(L)}^{H}\right)$ of L-aspartic acid, L-tartaric acid, and L-glutamic acid (Eqs.(1-6)). L-aspartic acid can release totaly three protons, two protons from carboxyl groups and one from amin group. L-tartaric acid contains no amino group, so two reported acidity constants regard to carboxyl groups. In case of L-glutamic acid two protons are released from carboxyl groups and one proton from amin group, which were showed as regarding sites. As we can see from these results, the stability constants of the binary complexes, such as M(L) (Figure 3) were refined separately using the titration data of this system in a $1: 1$, ligand: $\mathrm{M}^{2+}$ ratio in the same conditions of temperature and ionic strength (according Eqs.(9-10)), as they were in good agreement with reported value $[6,14]$. We didn't receive reasonable results for $K_{M(H ; L)}^{M}$. The stability constants of Table 2 show the following trends. The obtained order for Ttr is $\mathrm{Ca}^{2+}<\mathrm{Mg}^{2+}<\mathrm{Mn}^{2+}>\mathrm{Co}^{2+}<\mathrm{Cu}^{2+}>\mathrm{Zn}^{2+}$. The corresponding order for Glu and Asp is $\mathrm{Ca}^{2+}<\mathrm{Mg}^{2+}<\mathrm{Mn}^{2+}<$ $\mathrm{Co}^{2+}<\mathrm{Cu}^{2+}>\mathrm{Zn}^{2+}$. The last observed stability order for Glu and Asp follows the Irving-Williams sequence [15]. 


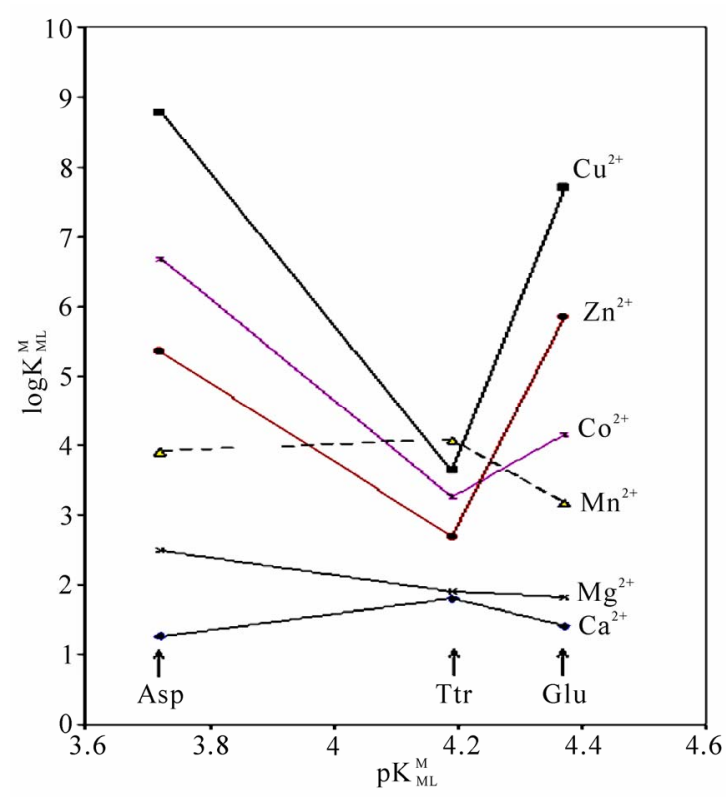

Figure 4. Relationship between $\log K_{M L}^{M}$ and $\mathrm{p} K_{H L}^{H}$ for $\mathrm{Ca}^{2+}, \mathrm{Mg}^{2+}, \mathrm{Mn}^{2+}, \mathrm{Co}^{2+}, \mathrm{Cu}^{2+}$, and $\mathrm{Zn}^{2+} 1: 1$ complexes of glutamate $\left(\mathrm{Glu}^{2-}\right)$, tartarate $\left(\mathrm{Ttr}^{2-}\right)$ and aspartate $\left(\mathrm{Asp}^{2-}\right)$. All plotted equilibrium constant values refer to aqueous solutions at $25^{\circ} \mathrm{C}, 0.1 \mathrm{M}, \mathrm{NaNO}_{3}$ (Table 1, second row \& Table 2).

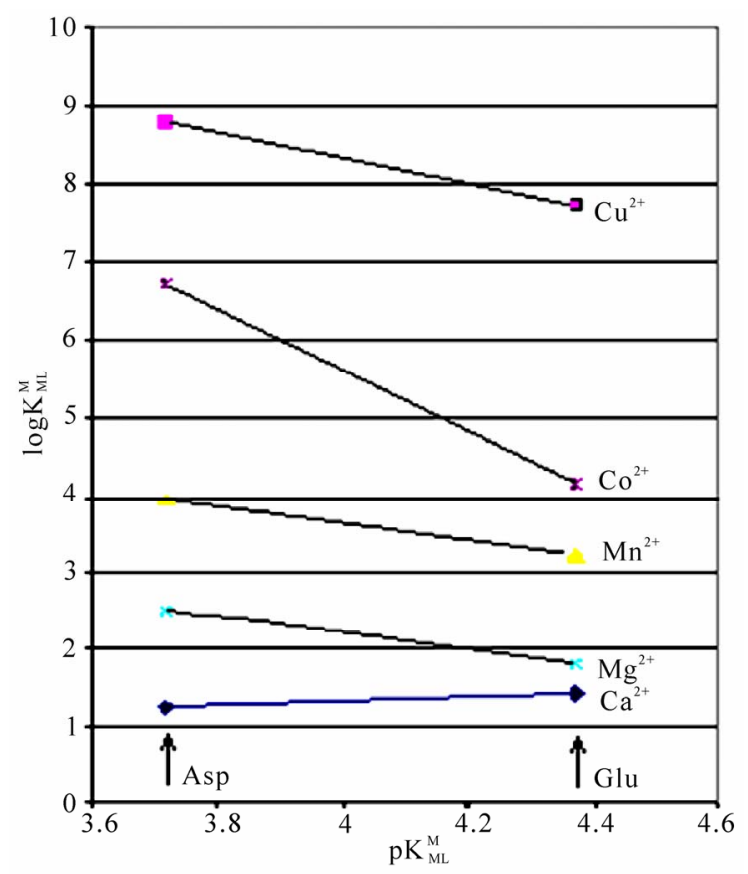

Figure 5. Relationship between $\log K_{M L}^{M}$ and $\mathrm{p} K_{H L}^{H}$ for $\mathrm{Ca}^{2+}, \mathrm{Mg}^{2+}, \mathrm{Mn}^{2+}, \mathrm{Co}^{2+}$, and $\mathrm{Cu}^{2+}, 1: 1$ complexes of glutamate $\left(\mathrm{Glu}^{2-}\right)$ and aspartate $\left(\mathrm{Asp}^{2-}\right)$. All plotted equilibrium constant values refer to aqueous solutions at $25^{\circ} \mathrm{C}, 0.1 \mathrm{M}, \mathrm{NaNO}_{3}$ (Table 1, second row \& Table 2).
As we can use from Figure 3, glutamate and aspartate chelate metal ions weakly via the amino nitrogen and carbonyl oxygen. A stronger chelation occurs upon amide nitrogen bound hydrogen by some metal ions such as $\mathrm{Cu}^{2+}$. This reaction occurs in neutral $\mathrm{pH}$ conditions $(\mathrm{pH} \approx$ 7) with $\mathrm{Cu}^{2+}$. A crystal structure of $\mathrm{M}^{2+}$ chelate with a structure analogous has been studied [16].

In Figure 4, we can consider the relationships between $\log K_{M L}^{M}$ and $\mathrm{p} K_{H L}^{H}$ for $\mathrm{Ca}^{2+}, \mathrm{Mg}^{2+}, \mathrm{Mn}^{2+}, \mathrm{Co}^{2+}$, $\mathrm{Cu}^{2+}$, and $\mathrm{Zn}^{2+} 1: 1$ complexes of glutamate $\left(\mathrm{Glu}^{2-}\right)$, aspartate $\left(\mathrm{Asp}^{2-}\right)$ and tartarate $\left(\mathrm{Ttr}^{2-}\right)$. The data are taken from Table 2. They also represent the stability constant values.

All the plotted equilibrium constant values refer to aqueous solution at $25^{\circ} \mathrm{C}, I=0 \mathrm{M}\left(\mathrm{NaNO}_{3}\right)$. As one can see, this relationship is not linear. The interesting point is that in case of hard metal ions such as $\mathrm{Ca}^{2+}$ and $\mathrm{Mn}^{2+}$, the results for $\mathrm{Ttr}$ show a maximum $\boldsymbol{\Delta}$ and in case of softer metal ions such as $\mathrm{Co}^{2+}, \mathrm{Cu}^{2+}$, and $\mathrm{Zn}^{2+}$, they show a minimum $\boldsymbol{\nabla}$. This is an indication, that for softer metal ions an additional interaction such as with amino group exists, which we can not find by Ttr.

In Figure 5, we can consider the relationships between $\log K_{M L}^{M}$ and $\mathrm{p} K_{H L}^{H}$ for $\mathrm{Ca}^{2+}, \mathrm{Mg}^{2+}, \mathrm{Mn}^{2+}, \mathrm{Co}^{2+}$, and $\mathrm{Cu}^{2+} 1: 1$ complexes of glutamate $\left(\mathrm{Glu}^{2-}\right)$ and aspartate $\left(\mathrm{Asp}^{2-}\right)$. However, the most important question is that: Is there a correlation between complex stability and donor groups' basicity? In other words, is there a linear relationship between $\log K_{M L}^{M}$ and $\mathrm{p} K_{H L}^{H}$ ? Based on

Figure 5, it seems that this is the case, where the data pairs for the systems of several metal ions are plotted. It is interesting to point out, that in contrast to increasing of basicity from Asp to Glu, show the stability of regarding complexes a decreasing trend.

Now, we are able to compare the stability constants of two species $\mathrm{M}(\mathrm{Glu})$ and $\mathrm{M}(\mathrm{Asp})$. It could easily distinguish that those constants of $\mathrm{M}(\mathrm{Asp})$ are generally larger than those of the corresponding $\mathrm{M}(\mathrm{Glu})$ species. This increased stability of the difference between the stability constants as defined in Eq.(11):

$$
\Delta \log \mathrm{K}=\log \mathrm{K}_{(\mathrm{Asp})}-\log \mathrm{K}_{(\mathrm{Glu})}
$$

Positive amount of $\Delta \log \mathrm{K}$ indicates that the $\mathrm{M}-\mathrm{Glu}$ complexes in case of $\mathrm{Mg}, \mathrm{Mn}$ and $\mathrm{Cu}$ are less stable than M-Asp complexes. These decreases of the stability, from Asp to Glu are based on larger ring size of Glu in M-Glu complexes. The calculated results of $\Delta \log \mathrm{K}$ for $\mathrm{Mg}, \mathrm{Mn}$ and $\mathrm{Cu}$ are $0.68,0.72$ and 1.08 , respectively.

The standard Gibbs free energy change for the reaction is related to the following equilibrium constant

$$
\Delta G^{\Theta}=-2.303 R T \log K
$$

As results, we received the according calculated values for Gibbs free energy change 3.88, 4.11 and 6.16 $\mathrm{kJmol}^{-1}$ for $\mathrm{Mg}, \mathrm{Mn}$ and $\mathrm{Cu}$, respectively. If we compare 
these values with the plotted results in Figure 5, we distinguish the decrease of stability constants from Asp - to Glu complexes, which refers to weaker interaction between metal ions and regarding ligands. This is a sequence of well-known ring size of the chelate. In case of M-Asp complexes is seven-member chelate ring and in M-Glu complexes is eight-member chelate ring. In case of $\mathrm{Ca}^{2+}$ the difference is within error range.

According to Irving and Williams, the order was as a consequence of the fact that the two parameters, which serve as a guide to the magnitude of the ionic (electrostatic) and covalent interactions (the reciprocal of the metal ionic radius and the sum of the first two ionization energies, respectively), both increase monotonically throughout the series from $\mathrm{Mn}$ to $\mathrm{Cu}$ and then decrease from $\mathrm{Cu}$ to $\mathrm{Zn}$. Thus, if water is replaced from $\left[\mathrm{M}\left(\mathrm{OH}_{2}\right) n\right]^{2+}$ by a ligand of better electron-donating power, then the gain in stability will increase with the ionization potential of the metal. If $\mathrm{H}_{2} \mathrm{O}$ is replaced by a ligand with a formal negative charge, the stability gain through electrostatic forces will increase as the radius of the metal cation decreases.

A series of metal-varied [ML(SC6F5)] model complexes related to blue copper proteins have been studied by a combination of absorption [12]. Thus, the "softer" thiolate ligand can have comparable covalent and ionic contributions to bonding, and these compensate to produce little change in the binding energy over the series of metal ions (open squares in Figure 6). For the "harder" ligands (F-, OH-, $\mathrm{H}_{2} \mathrm{O}$, etc.), the ionic term dominates and their binding energies are affected by changes in covalency over the series (open circles in Figure 6). It is the competition between these behaviors that produces the Irving-Williams series (solid circles in Figure 6) in stability constants.

Biological systems have the ability to selectively bind to metals taking advantage of the array of protein binding functionalities [17]. Short chain synthetic biopolymers also have unique, strong and selective binding properties offered by their constituent amino acids.

Interactions between aspartic acid (Asp) and cytidine5-monophosphate (CMP) in metal-free systems as well as the coordination of $\mathrm{Cu}$ (II) ions with the above ligands were studied. The composition and overall stability constants of the species formed in those systems were determined [18]. Amino acid chelated minerals, also referred to as chelated minerals or mineral chelates, are minerals that have been chemically engineered to become more bio-available to our body. Amino acids act as carriers to ship the much-needed minerals to the destination (the small intestine) where consumption takes place.

Elixir Industry has tested many self-claimed "mineral chelates" available on the market and found that most of them are merely mixtures of amino acids and inorganic minerals [19]. Why are amino acid chelated minerals superior to common inorganic minerals? Chelated minerals help protect vitamin stability. Inorganic metal ions may serve as a catalyst to further the oxidation and degradation of vitamins. Chelated minerals, on the other hand, are well shielded by bonded organic ligands, which we can consider in Figure 3. They will not come in contact with vitamin molecules; thus, the vitamins will be protected from oxidation and degradation. And since magma precipitation is prevented, chelated minerals will not absorb vitamins and cause them to become non-absorbable, problems that common inorganic mineral are known to cause. As we can see, in Figure 3, Ttr is not able to build three dentate chelate like Asp, so that metal ions are not enough shielded. As consequence metal ions can take part in substitution reactions.

There are different types of amino acids. L-aspartic acid plays a vital role in energy production and is a major excitatory neurotransmitter. It is involved in building DNA (genetic structures in cells), in carbohydrate metabolism \& protein metabolism. It helps detoxify ammonia in the body, helps reduce fatigue and depression, and it also supports liver protection. Mineral Chelates (for example AbSolu) are chelates of L-aspartic acid and one of the minerals such as calcium, magnesium and zinc.
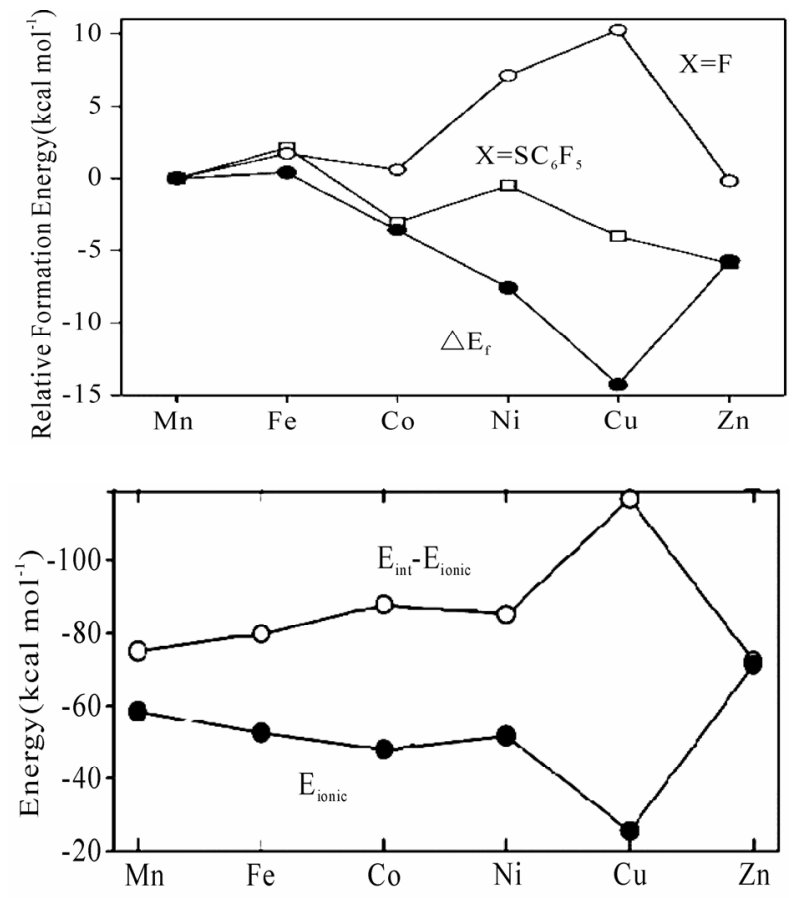

Figure 6. (a) Relative formation energies $\left(\mathrm{kcal} \mathrm{mol}^{-1}\right)$ of the metal-thiolatecomplexes, $[\mathrm{ML}(\mathrm{SC} 6 \mathrm{~F} 5)]$, and the metal-fluoride complexes, $[\mathrm{ML}(\mathrm{F})]$, andtheir difference, $\varnothing E f$.; (b) Ionic component of the $\mathrm{ML}^{+}-\mathrm{SC} 6 \mathrm{~F} 5$ - bonding energy, Eionic, and the difference, Eint - Eionic. Edward I. Solomon et al., Inorg. Chem. 44 (2005) 4947-4960. 
There are different types of amino acids. Nutrition scientists selected L-aspartic acid based on many additional benefits that come with it. Most of the competitors' products contain two or more crystalline water in their molecules. Theoretically those products should not be referred to as "chelates" and the bonding (if indeed exists) of amino acid molecules to mineral ions is vulnerable. These products are anhydrous chelates of two Laspartic acid molecules and a single metal ion. Based on the results of this work, we can draw the conclusion, that hard metal ions just with identical stability constantscould have similar interaction with glutamate. Even based on these, results of acidity constants reported (Table 2) glutamamic acid occurs in high organism in form of glutamate. Earlier works have reported the structure of glutamate complexes with some metal ions [20] such as $\mathrm{Co}^{2+}, \mathrm{Cu}^{2+}$ and $\mathrm{Zn}^{2+}$. These metal ions are able to have additional interactions with glutamate. This leads to building of macro-chelate (Figure 3).

\section{CONCLUSIONS}

It is shown, that Glu has identical complex properties as Asp i.e. the both amino acids have similar structure. The only difference is also the size of amino acids. The previous studies have shown, that Glu has special applications [21].

The glutamate industry have found that manufactured free glutamic acid, in the form of monosodium glutamate (MSG), hydrolyzed vegetable proteins, etc., etc., when added to the processed foods, masks off flavors and makes the blandest and cheapest foods taste wonderful. An other interesting point is the pharma- cological application of new generation of glutamate and aspartate complexes and it seems essential to understand their reaction mechanisms.

\section{REFERENCES}

[1] IUPAC-IUBMB Joint Commission on Biochemical Nomenclature. Nomenclature and Symbolism for Amino Acids and Peptides. Recommendations on Organic \& Biochemical Nomenclature, Symbols \& Terminology etc. Retrieved on 2007-05-17.

[2] Nelson, D.L., Cox, M.M., "Lehninger, principles of bio- chemistry" 3rd Edition, Worth Publishing: New York, 2000. ISBN 1-57259-153-6.

[3] Stryer, L. (1995) Biochemistry, 4th Edition, W.H. Freeman and Company New York.

[4] Chen, P.E., Geballe, M.T., Stansfeld, P.J., Johnston, A.R., Yuan, H., Jacob, A.L., Snyder, J.P., Traynelis, S.F. and Wyllie, D.J.A. (2005) Structural features of the glutamate binding site in recombinant NR1/NR2A N-Methyl-DLartate receptors determined by site-directed mutagenesis and molecular modeling. Molecular Pharmacology, 67, 1470-1484.

[5] Dunn, M.S. and Smart, B.W. (1963) "DL-Lartic, Acid" Organic Syntheses, 4, 55.

[6] Martel, A.E. (2006) Critical stability constants of metal complexes. 26.

[7] Xiao, S., Textor, M., Spencer, N.D., Sigrist, H. and Langmuir, (1998) 14, 5507.

[8] Konishi, Y., Shimaoka, J. and Asai, S. (1998) React. Func. Polym., 36, 197.

[9] Reichert, J. and Binner, J.G.P.J. (1996) Mater. Sci., 31, 231.

[10] Bonn, G., Reiffenstuhl, S., Jandik, P. and Chromatogr, J. (1990) 499, 669 .

[11] Bhattacharyya, D., Hestekin, J.A., Brushaber, P., Cullen, L., Bachas, L.G. and Sikdar, S.K. (1998) Membr. J. Sci. 141, 121.

[12] Solomon, E.I. et al., Inorg. Chem., 44(2005), 4947-4960.

[13] Sajadi, S.A.A. Alamolhoda, A.A. and Nazari Alavi, A. (2009) Scientica Iranica, in press.

[14] IUPAC Stability Conatants Database, Release 3, version 3.02, coplied by L.D. Pettit, H.K. J. Powel, Academic Software Timble, UK, (1998).

[15] Irving, H. and Williams, R.J.P.J. (1953) Chem. Soc., 3192-3210.

[16] Tsukihara, T. Katsube, Y. Bull. (1972) Chem. Soc. Jpn., 45, 1367.

[17] Guo, M.H., Zou, Wang, H. Kong, L. and Anal, J.N. (2001) Chim. Acta, 443, 91 .

[18] Romualda Bregier-Jarzebowska, Anna Gasowska, and Lechosław Lomozik, Bioinorganic Chemistry and Applications, 2008, Article ID 253971.

[19] The technology of achieving this structure is patented and was jointly developed by Elixir Industry, Las Vegas, NV 89104-7900, USA, and the Chinese National Institute of Pharmaceutical Industry.

[20] Miranda, J.L. and Felcman, J. (2003) Polyhedron, 22, 225-233.

[21] Reeds, P.J. et al., (2000) J. Nutrition, 130(45), 978S982S. 